\title{
Linguloidean brachiopods from the Lower Ordovician (Tremadocian) of northwestern Argentina
}

\author{
JuAN L. BENEDETTO \& DiEGO F. MUÑOZ
}

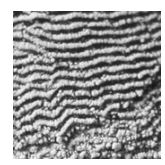

\begin{abstract}
The new obolid Torobolus subplanus gen. et sp. nov. from the lower Tremadocian Devendeus Formation, and the the new species Libecoviella tilcarensis and Leptembolon argentinum from the upper Tremadocian Santa Rosita Formation are described and illustrated. Libecoviella is typical of the upper Tremadocian Třenice Formation and Floian Klabava Formation of the Prague Basin and has been reported recently from Australia. Leptembolon has been recorded in the same Bohemian formations, but together with other taxa it forms the Thysanotos-Leptembolon Association present in northern Estonia and a series of high-latitude terranes. The record of Leptembolon and Libecoviella in the high- to temperate-latitude Central Andean region points to a peri-Gondwanan distribution of these genera. The presence of Bohemian-like obolids in northwestern Argentina suggests a migratory route linking the Central Andean Basin with north Gondwana and Perunica along the clastic platforms fringing the North African and Brazilian shields. - Key words: linguliform brachiopods, Ordovician, Argentina, biogeography.
\end{abstract}

\begin{abstract}
BENEDETTO, J.L. \& MUÑOZ, D.F. 2015. Linguloidean brachiopods from the Lower Ordovician (Tremadocian) of northwestern Argentina. Bulletin of Geosciences 90(2), 417-430 (6 figures). Czech Geological Survey, Prague. ISSN 1214-1119. Manuscript received October 14, 2014; accepted in revised form February 3, 2015; published online March 5, 2015; issued March 23, 2015.

Juan L. Benedetto (corresponding author) \& Diego F. Muñoz, Centro de Investigaciones en Ciencias de la Tierra, CICTERRA-CONICET, and Universidad Nacional de Córdoba, Vélez Sarsfield 1611, X5016GCA Córdoba, Argentina; jbenedetto@efn.uncor.edu,df.munoz@conicet.gov.ar
\end{abstract}

Linguliform brachiopods are very abundant in the thick and continuous Upper Cambrian-Ordovician clastic successions of northwestern Argentina, but to date they remain almost unknown. The first linguliform was reported by Kayser (1897) who described Lingulella ferruginea Salter from lower Tremadocian siltstones exposed near Iruya, in the Eastern Cordillera (Cordillera Oriental). Subsequently, a few taxa were briefly described and illustrated by Harrington (1937, 1938), including Acrotreta iruyensis Harrington, Obolus lampazarensis Harrington, Obolus (Broeggeria) salteri (Holl), Obolus (Broeggeria) elongatus Harrington, Obolus andinus Harrington, and Lingulella sp. Gutiérrez Marco \& Aceñolaza (1991) reassigned the type material of Obolus andinus (Harrington 1938, pl. 2, figs $12-15)$ to the rostroconchian mollusc Tolmachovia. All the remaining taxa described by Harrington are in need of revision. Other linguliforms, such as Lingulepis? sp., Dignomia muensteri d'Orbigny, and Ectenoglossa sp., have been mentioned in the context of taphonomic analyses of the so-called "lingulid shell beds" recorded from different localities of NW Argentina (Aceñolaza et al. 2003), but this material remains undescribed.

This is the first of a series of papers concerning the taxonomy, palaeoecology and biogeography of Late Cambrian and Ordovician linguliforms from northwestern Argentina, which include a varied suite of obolids, acrocretids, and siphonotretids. Preliminary conclusions on the fauna described in this paper were recently advanced in the $4^{\text {th }}$ International Paleontological Congress (Muñoz \& Benedetto 2014). In the present study we report well-preserved lingulate brachiopods from the upper part of the Santa Rosita Formation (late Tremadocian age) exposed in the Tilcara Range, and from boulders within the Devendeus Formation (early Tremadocian age) cropping out in the Parcha area (Fig. 1). The fauna consists of acrotretids (not included here), the new obolid genus Torobolus, new species of Libecoviella, Leptembolon, and an unidentified species of Ectenoglossa.

\section{Stratigraphy and age}

The large Central Andean Basin extends through northwestern Argentina, northern Chile, Bolivia, and Perú. The southern part of the basin is superbly exposed in the Cordillera Oriental (Eastern Cordillera) of northwestern Argentina where the Upper Cambrian-Middle Ordovician strata attain over 3,800 $\mathrm{m}$ in thickness. The succession exposed in 


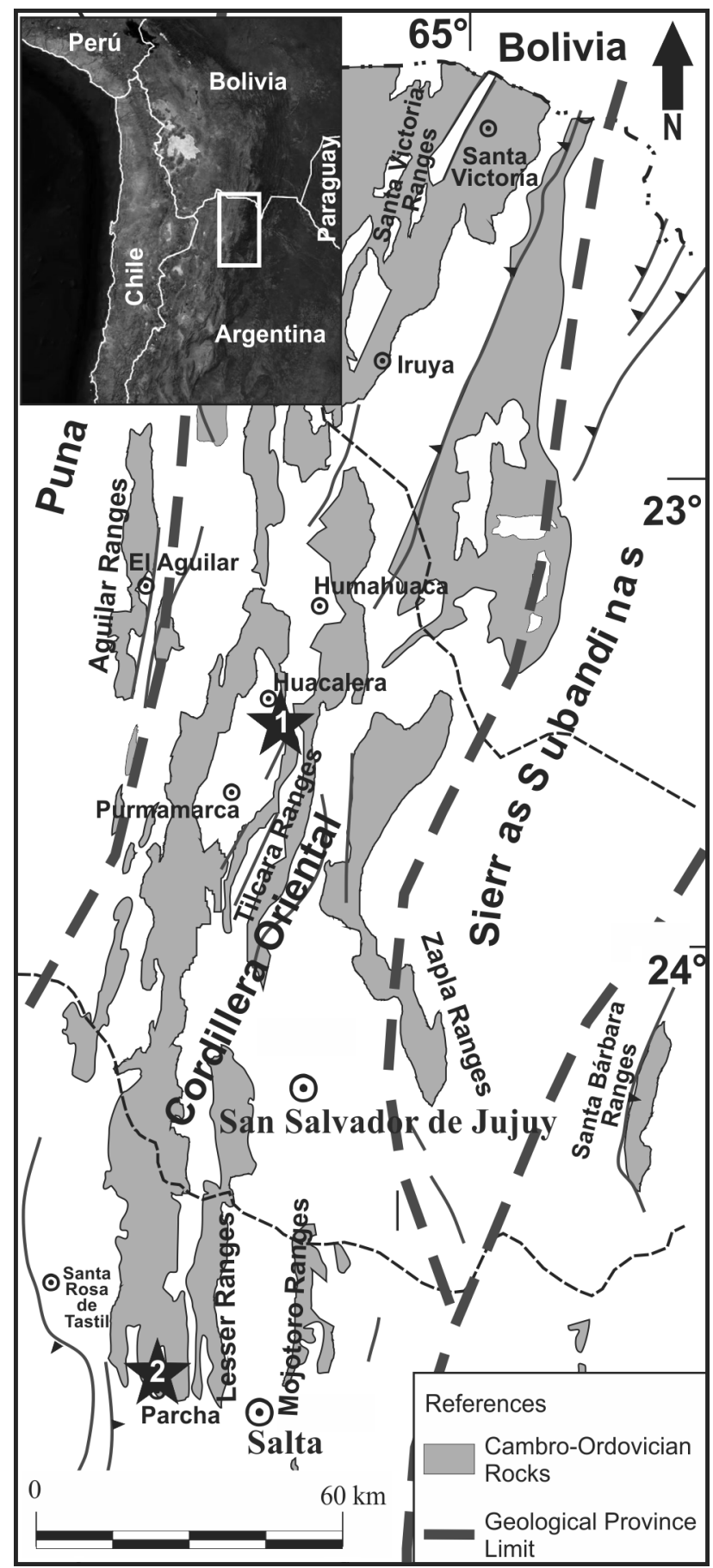

Figure 1. General location of the studied area (upper left), map of the Cordillera Oriental of northwestern Argentina showing exposures of Cambrian-Ordovician rocks (grey), and location of sampled stratigraphic sections mentioned in the text (black stars); 1 - Quebrada Humacha; 2 - Parcha.

the Santa Victoria area (Fig. 1) was referred by Turner (1960) to the Santa Victoria Group, which was subdivided into the Santa Rosita Formation (Furongian-Tremadocian) and the Acoite Formation (latest Tremadocian, Floian, and
Dapingian). So far, the stratigraphic relationships of the type area succession with the numerous informal and formally defined units exposed in other localities (e.g. Harrington \& Leanza 1957, Moya 2002, Astini 2003) have not yet been completely elucidated because of the lack of basin-scale stratigraphic and palaeontological analyses. The Santa Victoria Group unconformably overlies the Cambrian Mesón Group, which consists of Skolithos-rich reddish quartz sandstones and siltstones deposited in tide-dominated environments (Mángano \& Buatois 1999, 2004a).

In its type area, the Santa Rosita Formation consists of about $1,400 \mathrm{~m}$ of fossiliferous dark grey shales and mudstones interbedded with greenish sandstones. About $120 \mathrm{~km}$ to the south, the $\mathrm{ca} 1,100 \mathrm{~m}$ thick continuous succession exposed in the Tilcara Range along the eastern margin of the Río Grande (Fig. 1) has been the focus of detailed stratigraphic studies by Buatois \& Mángano (2003) and Buatois et al. (2006). The integration of sedimentological, ichnological and sequence stratigraphy data led these authors to divide the Santa Rosita Formation into six members (formerly recognized as separate formations by Harrington \& Leanza 1957, and Moya 1988) named, in ascending order, Tilcara, Casa Colorada, Pico de Halcón, Alfarcito, Rupasca, and Humacha. The lowermost Tilcara Member was interpreted as representing the infill of incised valleys by sandy braided fluvial systems during the lowstand phase, followed by tide-dominated estuarine sandstones deposited during the transgressive systems tract (Buatois \& Mángano 2003). The transgression culminates with wave-influenced shallow-shelf mudstones and rippled sandstones (Casa Colorada Member), which on the basis of the trilobites of the Parabolina frequens argentina Zone is of Late Cambrian (Furongian) age (Zeballo \& Tortello 2005). The Pico de Halcón Member reflects deposition of tidal flats and subtidal sandbar complexes infilling valleys incised into the "Casa Colorada platform" during a relative sea-level fall (Buatois et al. 2006). The overlying interval of greenish mudstones and coarsening upwards heterolithic with hummocky cross stratification (Alfarcito Member) was deposited in a storm-dominated marine platform, followed by new transgressive episodes including black shales deposited under dysoxic conditions. Towards the top, a succession of alternating shales and sandstones reflects the onset of a progradation (Rupasca Member). The Santa Rosita Formation culminates with shoreface and shoreface/offshore transition deposits (Humacha Member). These consist mainly of thick-bedded amalgamated sandstones with hummocky cross-stratification recording high-energy oscillatory and combined flows during storm events, alternating with richly fossiliferous inner-shelf mudstones and siltstones (Mángano \& Buatois 2004b). Poorly sorted shell concentrations of variably fragmented brachiopod shells and trilobite sclerites are frequent at the 


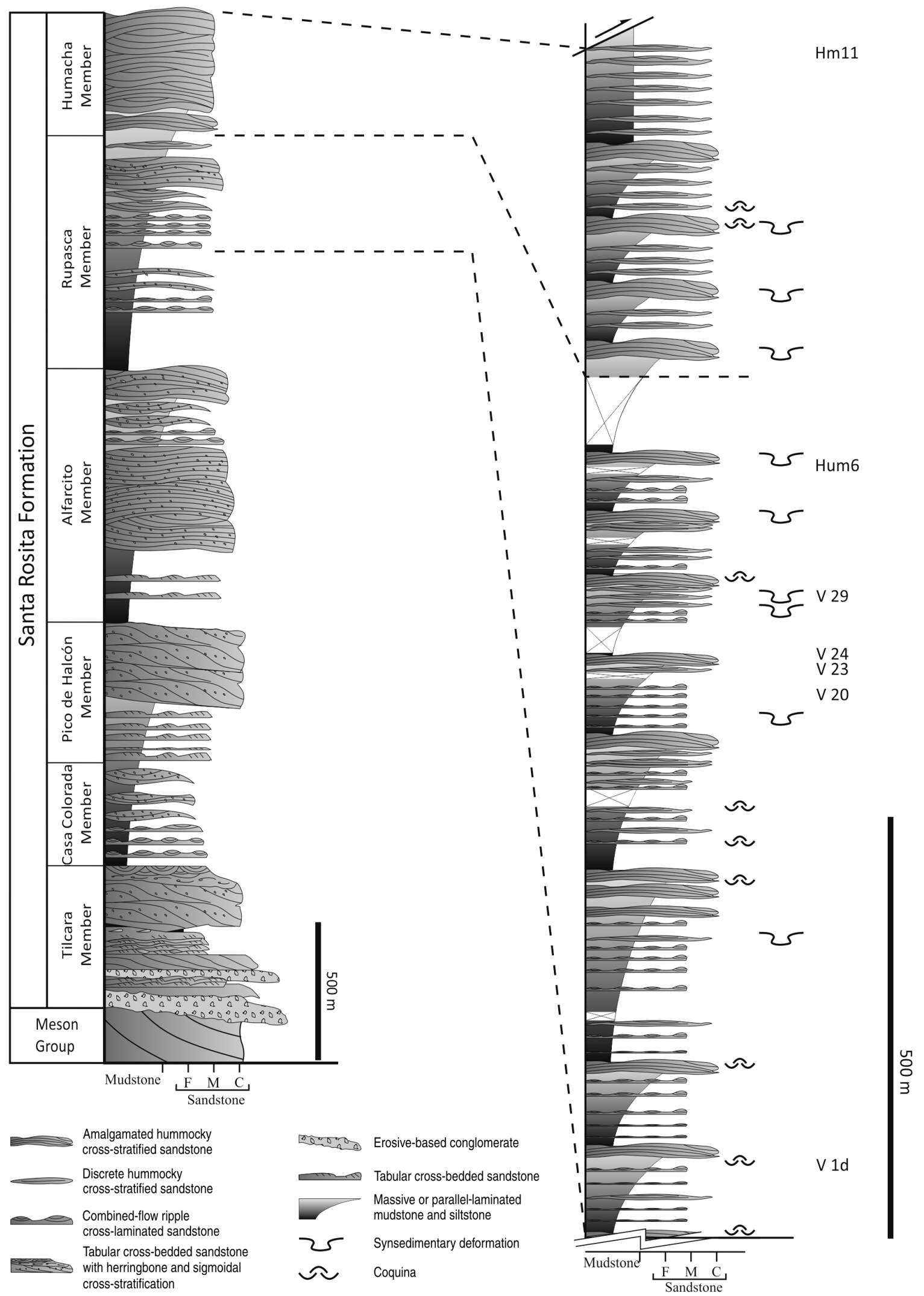

Figure 2. Composite stratigraphic succession of the Santa Rosita Formation in the Tilcara Range, Quebrada de Humahuaca area (left) (after Buatois \& Mángano 2003), and detail of the sampled interval at Quebrada Humacha showing fossiliferous levels mentioned in the text (right). 
base and within the sandstone beds (Marengo 2010). Most lingulate brachiopods described herein were collected from mudstones and fine-grained sandstones belonging to both the Rupasca and the Humacha Members of the Santa Rosita Formation (Fig. 2).

According to Zeballo et al. $(2005,2008)$ conodonts of the Paltodus deltifer Zone first appear in the lower part of the Rupasca Member, while the Acodus deltatusParoistodus proteus Zone has been documented through the entire Humacha Member. The upper part of the Rupasca Member at Quebrada Humacha yielded the graptolite Adelograptus cf. altus Williams \& Stevens, 1991 (Zeballo et al. 2008), a component of the Aorograptus victoriae-Kiaerograptus Zone proposed by Ortega \& Albanesi (2005) for northwest Argentina, which is partially equivalent to the Acodus deltatus-Paroistodus proteus Zone. However, a subsequent revision of new samples from Quebrada Humacha indicates that both the Rupasca and Humacha members fall within the range of the Paltodus deltifer Zone (Zeballo \& Albanesi 2013) of late Tremadocian age ( $\operatorname{Tr} 2$ according to the tripartite time slices subdivision proposed by Bergström et al. 2009).

Trilobites are abundant throughout the Santa Rosita Formation. The lower part of the Humacha Member has been attributed to the sparsely fossiliferous unzoned interval between the Bienvillia tetragonalis and Notopeltis orthometopa biozones (Salas \& Vaccari 2012), while its upper part could be assigned to the upper Tremadocian Notopeltis orthometopa Zone (Harrington \& Leanza 1957, Waisfeld \& Vaccari 2008a, Zeballo \& Albanesi 2013).

The rhynchonelliforms from the Tilcara Range are currently under study (Muñoz in progress). The Humacha section contains low-diversity rhynchonelliform assemblages dominated by Nanorthis purmamarcaensis Benedetto and Lipanorthis spp. (Muñoz \& Benedetto 2013, Muñoz et al. 2013). The former ranges from the $P$. deltifer to the lower half of the P. proteus/A. deltatus conodont zones (Benedetto 2007), whereas different species of the genus Lipanorthis have been recorded from the top of the Cordylodus angulatus Zone to the upper Floian (Benedetto \& Carrasco 2002, Harper et al. 2004, Benedetto \& Muñoz 2013).

The second sampled locality yielding the new genus Torobolus is located along the footpath to the Parcha village, between Angosto de Lampazar and Abra de Sococha, on the northwestern margin of the Quebrada del Toro (Fig. 1). In this area the Lampazar, Cardonal, Saladillo and Parcha formations have been defined (Keidel 1943, Harrington \& Leanza 1957). This succession, about 1,700 m thick, is time-equivalent to the Santa Rosita Formation (discussed above). The stratigraphy of the area has been revised by Astini (2003) who recognized a ca 45 m thick debris flow unit (the Devendeus Formation), which fills a palaeovalley excavated into the underlying cross-bedded sandstones of the Cardonal Formation (Fig. 3). Torobolus subplanus gen. et sp. nov. is found in fossil-rich boulders mostly derived from the shallow-water Cardonal Formation and redeposited in the Devendeus Formation. Conodonts from these beds, formerly referred to the Cardonal Formation, belong to the Cordylodus angulatus Biozone (Tortello \& Rao 2000). Shell concentrations are dominated by the brachiopod Nanorthis calderensis calderensis Benedetto, which is confined in the northwestern basin to the lower Tremadocian P. angulatus Zone, probably its upper part (Benedetto 2007). The overlying shaly mudstones (Saladillo Formation) yielded conodonts of the Paltodus deltifer Zone and contain well-preserved rhynchonelliform faunas (Harper et al. 2004, Villas et al. 2009).

\section{Biogeographic remarks}

To date, information on Furongian-lower Tremadocian linguliforms from the Central Andean Basin of Argentina and Bolivia is too fragmentary to perform multivariate analyses like those carried out by Popov et al. (2013, fig. 10.3) for the Middle Ordovician linguliforms, and by Benedetto et al. (2009, fig. 7) for the Floian-lower Dapingian rhynchonelliforms. Overall, the fauna described herein displays clear Bohemian affinities. Libecoviella is a typical obolid of the upper Tremadocian and Floian strata of the Prague Basin (Třenice and Klabava formations, respectively). Outside Perunica it has only been reported from Australia (Brock \& Holmer 2004). As well as occurring in the same Bohemian formations, the type species of Leptembolon comes from northern Estonia and it has also been recorded in South Urals (Popov \& Holmer 1994). Together with other taxa it forms the Thysanotos-Leptembolon Association present in Baltica and a series of high-latitude terranes (e.g. Alborz, Perunica, Central Iran). The record of Leptembolon and Libecoviella in the high- to temperate-latitude Central Andean region attests to a peri-Gondwanan distribution of these genera. However, the presence of the new genus Torobolus suggests a certain degree of isolation of the Central Andean Basin from other Gondwanan regions during the Lower Ordovician, in accordance with the evidence from rhynchonelliform brachiopods (Benedetto et al. 2009, and references therein), trilobites (Waisfeld \& Vaccari 2003, 2008b), and bivalves (Sánchez 2005, 2008).

Mergl (1997a) and Bednarzcyk (1999) suggested that the Thysanotos-Leptembolon Fauna had a peri-Gondwanan origin. This is supported by the finding of Libecoviella and Leptembolon in strata slightly older $(\operatorname{Tr} 2)$ than those yielding these genera in the Perunica terrane, together with the occurrence of Thysanotos in the Late Cambrian of Central Iran (Bassett et al. 1999, Popov et al. 2013). The role of the Central Andean Basin as site of origination of some rhynchonelliform brachiopod lineages, however, is documented by the occurrence in the lower 
Tremadocian of NW Argentina of the billingselloid brachiopod Chaniella Benedetto (2009), which has been considered a basal form of the entire polytoechoid clade (Benedetto 2009, Topper et al. 2013). Another example is the record of Protorthisina simplex Benedetto - the earliest rhynchonelliform brachiopod so far discovered from the Central Andean Basin - in strata of Furongian age (Lampazar Formation). Morphological and stratigraphical evidence suggest that this species is the stem group of both nanorthid and euorthisinid clades, and that it gave origin to the genus Kvania, which is represented by at least three species in the latest Cambrian and lower Tremadocian strata of NW Argentina and Bolivia (Benedetto 2007). Kvania is known elsewhere from the upper Tremadocian of Bohemia (Mergl 1984) and northeast Bavaria, Germany (Villas in Sdzuy et al. 2001). The record of Kvania and the Bohemian-like obolids described herein suggest a migratory route linking the Central Andean Basin with north Gondwana and Perunica along the clastic platforms fringing the Brazilian and North African cratons. Since the late Dapingian-Sandbian the Central Andean brachiopods and bivalves display unambiguous affinities with the Mediterranean faunas, as has been demonstrated in numerous papers (Havlíček \& Branisa 1980; Babin 1993; Sánchez \& Babin 1993; Benedetto \& Sánchez 2003; Benedetto et al. 2009; Benedetto 2013, 1014).

\section{Systematic palaeontology}

The studied specimens are deposited in the palaeontological collection of the Centro de Investigaciones Paleobiológicas - CICTERRA (Centro de Investigaciones en Ciencias de la Tierra), CONICET and Universidad Nacional de Córdoba. All the types and figured specimens appear with the institutional abbreviation CEGH-UNC.

Class Lingulata Goryanskiy \& Popov, 1985

Order Lingulida Waagen, 1885

Superfamily Lingulacea Menke, 1828

Family Obolidae King, 1846

Subfamily Obolinae King, 1848

\section{Genus Libecoviella Mergl, 1997}

Type species. - Lingula arachne Barrande, 1879. Třenice Formation, Tremadocian. Prague Basin, Czech Republic.

\section{Libecoviella tilcarensis sp. nov.}

Figure 4A-J

Holotype. - CEGH-UNC 25938, external mould of a pedicle valve (Fig. 4D).

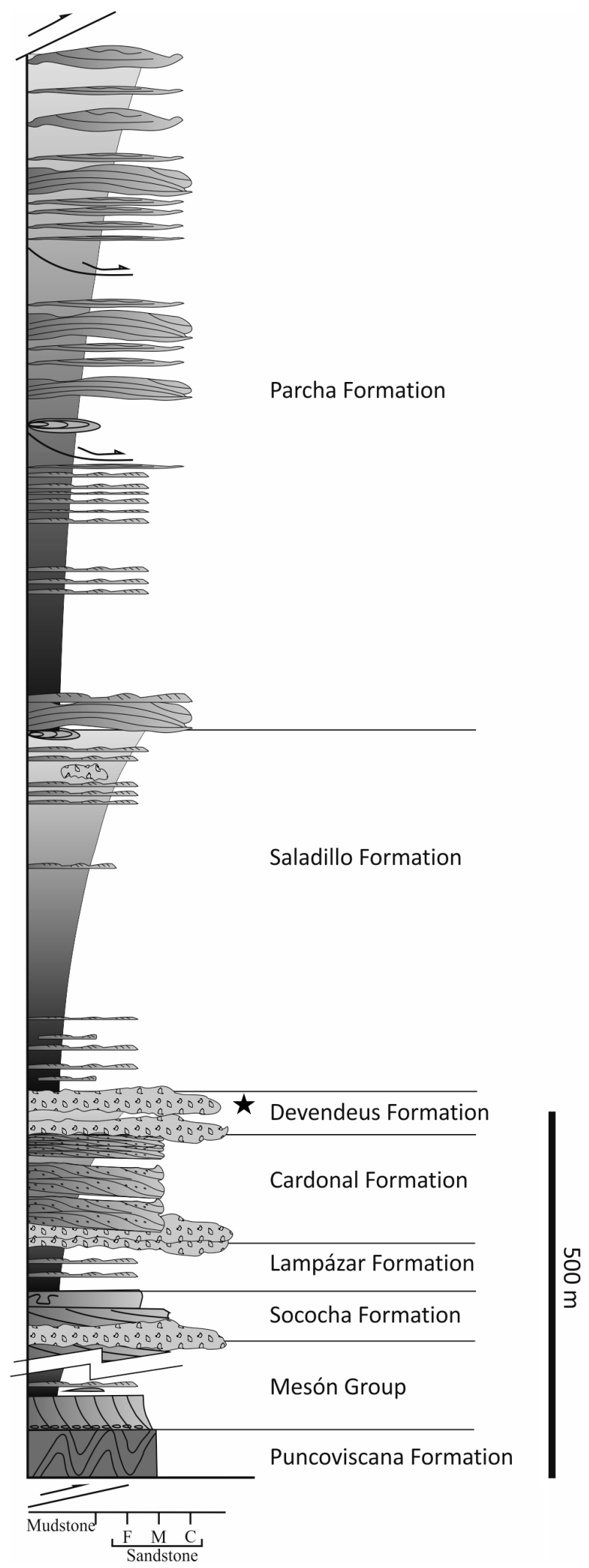

Figure 3. Columnar stratigraphic succession at the Parcha region, Cordillera Oriental. Fossils (black star) come from boulders within the debris-flow unit (Devendeus Formation) (modified from Astini 2003). 
Paratypes. - CEGH-UNC 25931 to 25937.

Type locality. - Quebrada Humacha, eastern margin of Quebrada de Humahuaca, Jujuy Province, Argentina.

Type horizon. - Uppermost Santa Rosita Formation (Rupasca Member), levels V20, V23, V29, Hum6.

Etymology. - From the Tilcara Range.

Description. - Shell large, up to $18 \mathrm{~mm}$ long, thick-walled, subequally biconvex. Ventral valve elongate oval in outline with maximum width at about two-third of the shell length (average length/width ratio 1.18); posterior region acuminate; posterolateral margins straight, subtending a $85^{\circ}-95^{\circ}$ angle; anterior margin uniformly rounded. Dorsal valve almost circular in outline with rounded beak, deepest at the posterior third. Ventral pseudointerarea orthocline, proportionally large, undercut anteriorly, extending for about $15 \%$ of the valve length, occupying $50 \%$ of the valve width; pseudointerarea gently concave, its surface covered by $10-12$ distinct growth lines; posterolateral margins delimited by a narrow carina running parallel to the valve margin. Flexure lines not discernible. Pedicle groove deep, U-shaped in profile, slightly expanding anteriorly. Dorsal pseudointerarea short, arcuate, gently raised above valve floor, weakly striated. External ornamentation of fine closely-spaced terrace lines averaging 9 per $\mathrm{mm}$ in the central region of shell, covering uniformly the entire surface of both valves. Terrace lines display a well-defined zigzag pattern on most of the shell surface but they tend to be undulating and almost subparallel on the lateral slopes. Crests of successive zigzag ridges roughly aligned simulating radial ornamentation. Fine concentric rugae present on the posterior third of the shell fading anteriorly. Prominent growth lamellae concentrated near the anterior margin. Exfoliated valves with well-defined radial striations. Ventral interior with visceral field slightly raised on the valve floor. Muscle scars and vascular system indistinct. Dorsal interior with slender, almost straight vascula lateralia with subtending angle of $70^{\circ}$. Median septum narrow extending up to two-thirds valve length. Central muscle scars elongate located along midline of the valve. Posterior half of both valves covered by rounded pits enlarged posterolaterally.
Remarks. - The genera Westonia Walcott, Westonisca Havlíček, Josephobolus Mergl, and Libecoviella Mergl have in common a distinctive external ornamentation consisting of variably developed undulating terrace lines, which have been interpreted as an adaptive feature for burrowing (Savazzi 1986, Mergl 1997b). Besides ornamentation, these genera are broadly similar in having a thick-walled shell with a strongly convex acuminate umbonal region and a deep pedicle groove. Generic differentiation of such "westoniid-like" obolids is relatively subtle and relies essentially on the relative convexity of valves, size of ventral pseudointerarea, morphology of pedicle groove, development of flexure lines, and especially details of the ornamentation pattern. The new Argentine species is assigned to Libecoviella Mergl, 1997b on the basis of its strongly acuminate and apically convex ventral valve, deep subparallel-sided pedicle groove, indiscernible flexure lines, and uniform terrace lines over the entire surface. The proportionally large undercut pseudointerarea of the new species is comparable to that of Josephobolus, but in that genus the pedicle groove strongly expands anteriorly and the anterolateral sectors of the valve display a network of pits at the intersection of terrace lines (Mergl 1996, 1997b). In addition, in our material internal pits are considerably smaller and less prominent than in Josephobolus (cf. Mergl 1997b, fig. 8A, B). Westonisca is closely related to Libecoviella from which differs in having a pseudointerarea with well-defined flexure lines and prominent undulating terrace lines increasing in size anteriorly (Havlíček 1982, Mergl 1997b). The Argentine material resembles Westonia in the ornamentation pattern but differs in its dorsibiconvex profile, in its parallel-sided pedicle groove, and in lacking flexure lines.

The ornamentation of fine uniform terrace lines of Libecoviella tilcarensis sp. nov. is closely comparable to that of the type species Libecoviella arachne Barrande, 1879, from the upper Tremadocian Třenice Formation of the Czech Republic (Havlíček 1982, Mergl 1997b). However, the Bohemian form can be distinguished by its subtriangular outline, its more strongly acuminate beak, and its narrow and short pedicle groove. The new species is closely related to Libecoviella ovata (Havlíček, 1982), present in the upper Tremadocian of the Barrandian area, in its large size (largest shells attain $18 \mathrm{~mm}$ in length), suboval outline, and moderate shell convexity. The external ornamentation of both

Figure 4. Libecoviella tilcarensis sp. nov. Locality: Tilcara Range, Quebrada Humacha. Age: late Tremadocian. • A-C - external mould of ventral valve (A), latex cast of exterior (B), and detail of the ornamentation (C) (CEGH-UNC 25931a). • D - latex cast of exterior of ventral valve (holotype CEGH-UNC 25938). • E - internal mould of dorsal valve showing vascula lateralia (CEGH-UNC 25935). • F - internal mould of ventral valve (CEGH-UNC 25936). $\bullet \mathrm{G}$ - latex cast of exterior of dorsal valve (CEGH-UNC 25934). $\bullet \mathrm{H}$, I - internal mould of ventral valve (H), and latex cast of interior of ventral valve (CEGH-UNC 25933). • J - internal mould of ventral valve (CEGH-UNC 25932). Torobolus subplanus gen. et sp. nov. Locality: Footpath to the Parcha village, Quebrada del Toro; Age: early Tremadocian. $\bullet \mathrm{K}, \mathrm{L}-$ partly exfoliated dorsal valve (K) and detail of ornamentation (L) (CEGH-UNC 25995). Scale bar $=5 \mathrm{~mm}$ unless otherwise noted. 

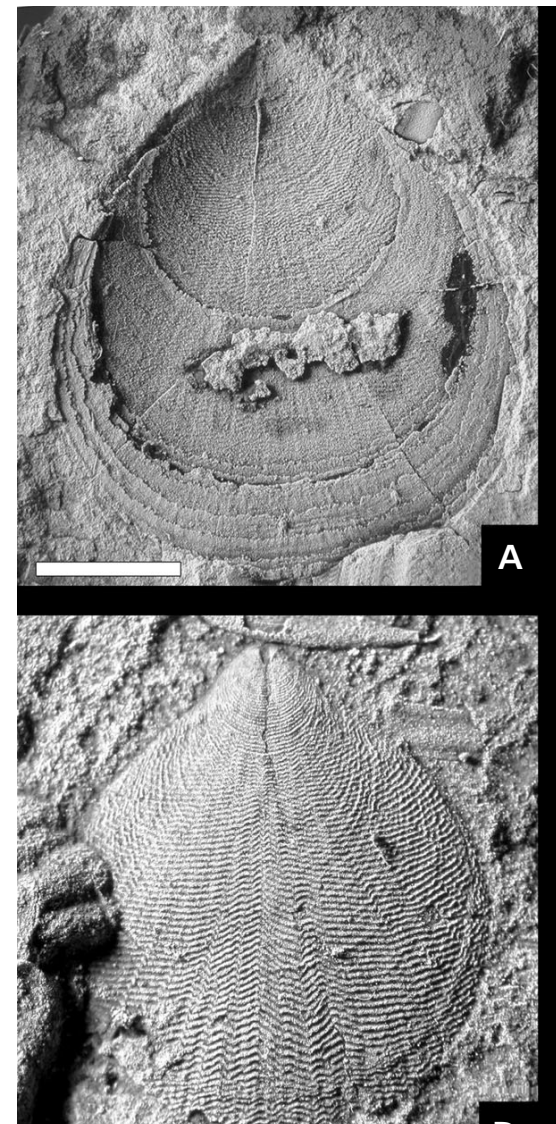

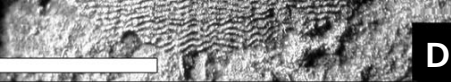
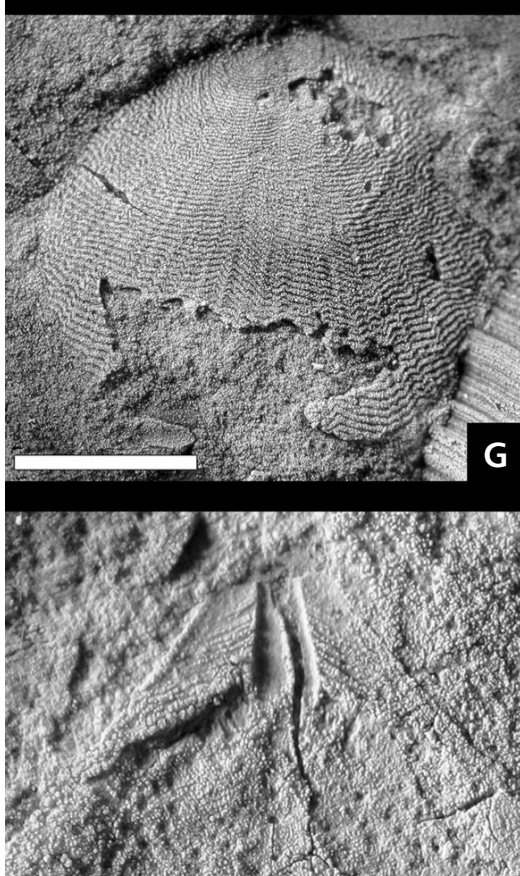

x $0 \%$
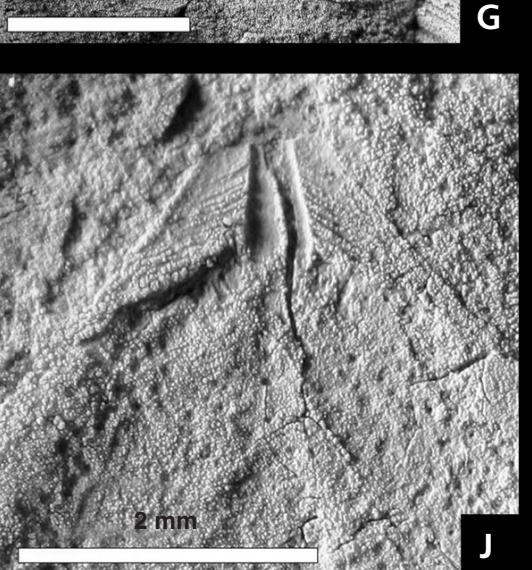
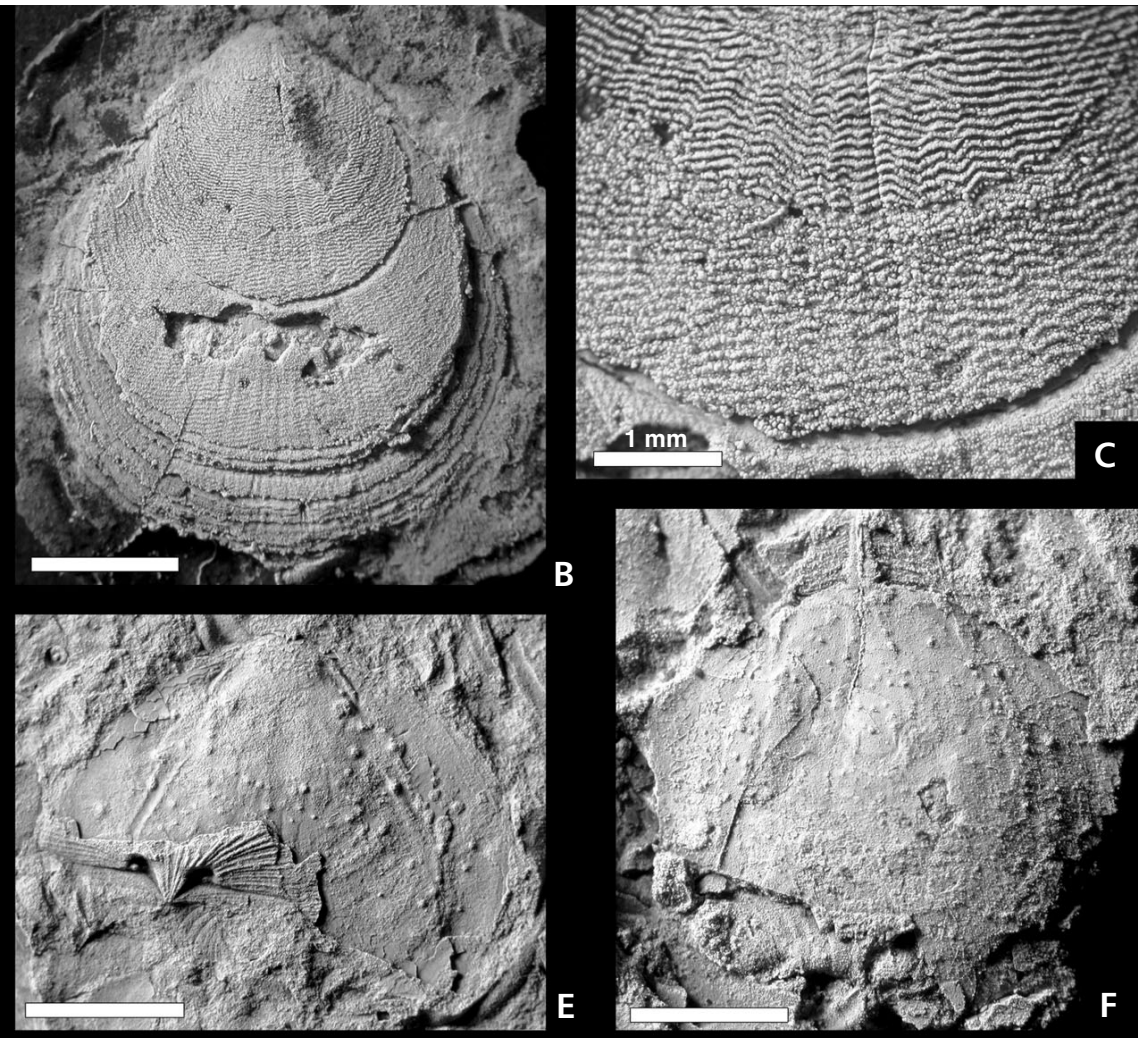

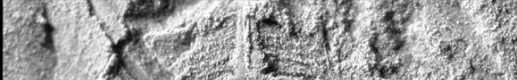

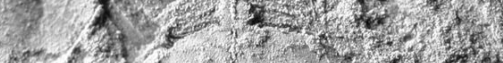
2. (1)
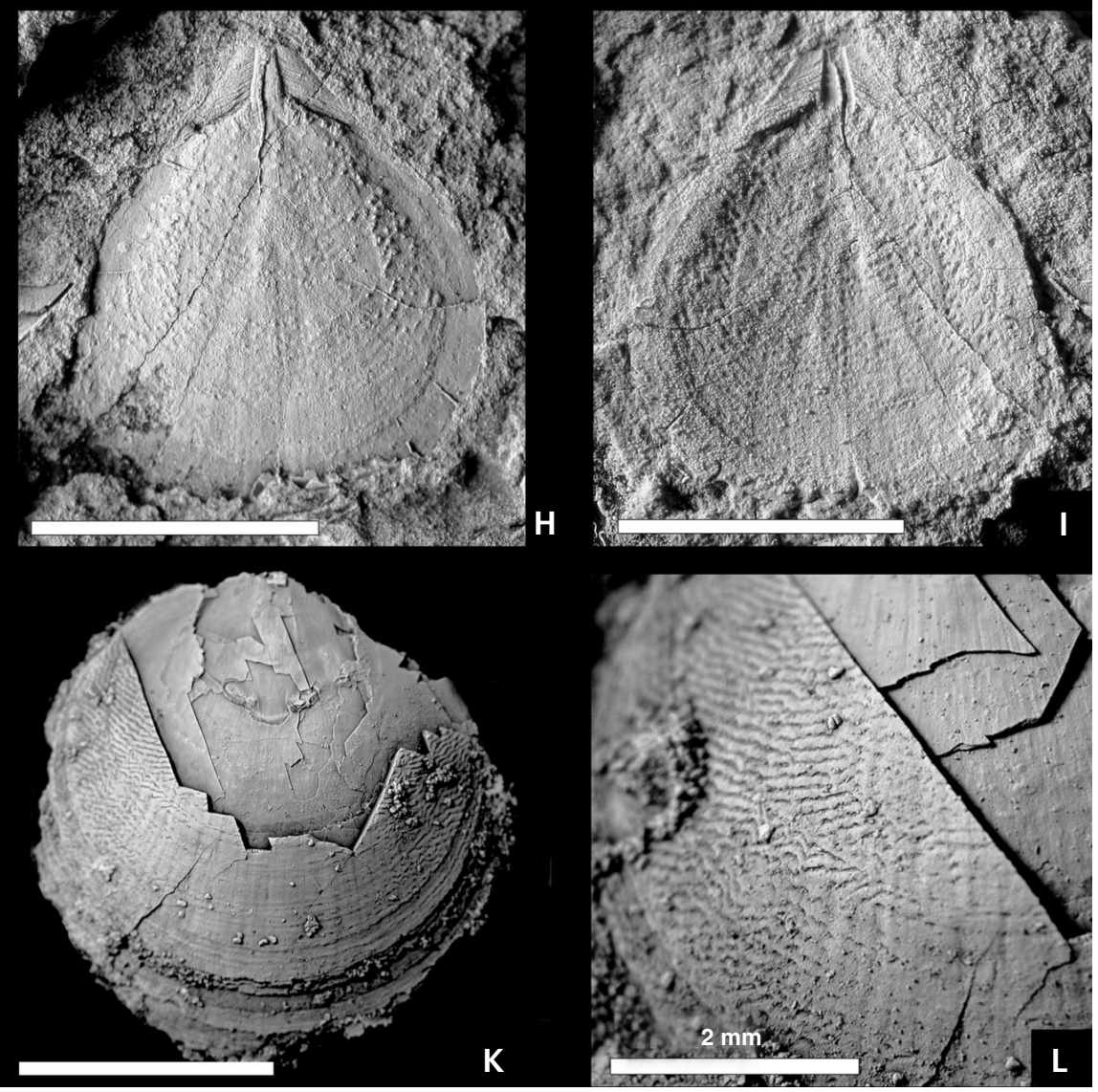
species is also comparable. The new species L. tilcarensis, however, differs in its less elongate ventral shell, the average length/width being lower (1.18) than in L. ovata (1.36 calculated on the basis of the complete specimen illustrated by Mergl 1997b, fig. 6I). In addition, the Argentine specimens do not show evidence of trilobation of the anterior commissure and the ventral pseudointerarea is proportionally larger, representing about $50 \%$ of valve width instead of $25 \%$ in the Bohemian species. Libecoviella brlohicensis Mergl, 1997b, from the upper Treamadocian Lipoltice Formation, is relatively similar to L. arachne and differs from L. tilcarensis in the more elongate subtriangular shell outline and in having a strongly acuminate beak. Outside Bohemia, the sole species described is Libecoviella divaricata Brock \& Holmer, 2004, from the Emanuel Formation of Western Australia, of Floian age. The Australian species shares with L. tilcarensis sp. nov. a large ventral pseudointerarea occupying about $50 \%$ of valve width, but clearly differs in having well-defined flexure lines, in its much smaller size (largest shells attain $6 \mathrm{~mm}$ long), and its elongate ovoid outline (length/width ratio 1.42 ). The ornamentation of $L$. divaricata, though typical of the genus, is more delicate and the zigzag pattern is less prominent than in L. tilcarensis and the Bohemian species.

\section{Genus Torobolus gen. nov.}

Type species. - Torobolus subplanus gen. et sp. nov. Boulders from the Devendeus Formation, lower Tremadocian, Salta Province, Argentina.

Etymology. - After Quebrada del Toro, near to the fossiliferous locality.

Diagnosis. - Large thick-shelled ventribiconvex obolid ornamented by divaricate zigzag terrace lines of almost uniform size. Ventral pseudointerarea with flexure lines. Ventral visceral area subrhomboidal, raised anteriorly. Dorsal valve subcircular, gently convex, with narrow arcuate pseudointerrarea lacking median depression. Dorsal muscle system consisting of a pair of medially adjacent anterolateral scars, a pair of smaller central scars at about one-third valve length, a pair of widely separated postero- lateral muscle scars, and a pair of minute rounded umbonal scars. Dorsal interior with distinct arcuate vascula lateralia running almost parallel to the valve margin.

Remarks. - The lower Tremadocian specimens from the Parcha section share with the Bohemian genus Westonisca Havlíček, 1982 the large ventral pseudointerarea with distinct flexure lines, broad dorsal pseudointerarea, large and anteriorly raised ventral visceral area with well-impressed muscle scars along its anterior edge, and terrace lines becoming indistinct on the median and anterior regions of the valve. However, our material differs from Westonisca lamellosa (Barrande, 1879) in having (1) ventribiconvex shell instead of dorsibiconvex, (2) narrow dorsal pseudointerarea lacking flexure lines and median depression, (3) smaller size of terrace lines which do not increase in size anteriorly, and (4) different arrangement of dorsal muscle scars. Such a combination of features justifies assigning this material to a new linguloid genus. The elevated ventral platform not extending beyond the valve midlength is reminiscent of certain elkaniids (e.g. Broeggeria, Monobolina), but because larval pitting is not preserved it is attributed tentatively to the obolids. The new genus Torobolus can easily differentiated from Libecoviella in having ventribiconvex shell profile, well-defined rhomboidal ventral visceral area, narrower dorsal pseudointerarea lacking median depression, conspicuous arcuate dorsal vascula lateralia, and a different arrangement of dorsal muscle scars (Fig. 5E). Most of these features also are useful to distinguish Torobolus from Josephobolus Mergl, 1997b, which is further distinguished by its much larger internal pits and a regular network of pits at the crossing of terrace lines. Although the latter feature has not been observed in Torobolus, preservation of the ornamentation in our material is not good enough for a detailed comparison.

Species assigned. - Only the type species.

\section{Torobolus subplanus sp. nov.} Figures 4K-L, 5A-I

Holotype. - Internal mould of dorsal valve CEGH-UNC 25989 (Fig. 5D, E).

Figure 5. Torobolus subplanus gen. et sp. nov. Locality: footpath to the Parcha village, Quebrada del Toro. Age: early Tremadocian. • A, B - internal mould of ventral valve (A) and latex cast (B) showing raised visceral area (CEGH-UNC 25990). • C - exfoliated dorsal valve (CEGH-UNC 25997). $\bullet$ D, E - internal mould of dorsal valve (D) and detail muscle scars (E) (holotype CEGH-UNC 25989). • F - internal mould of dorsal valve (F) (CEGH-UNC 25988). $\bullet \mathrm{G}$ - internal mould of dorsal valve showing converging vascula media (CEGH-UNC 25993). • H - exterior of partly decorticated ventral valve showing ornamentation (CEGH-UNC 25991). • I - partly decorticated dorsal valve (CEGH-UNC 25989). Ectenoglossa sp. Locality: Tilcara Range, Quebrada Humacha. Age: late Tremadocian. • J - internal mould of ventral valve showing divergent lateral margins $(\mathrm{CEGH}-\mathrm{UNC} 25956) \cdot \mathrm{K}_{-}$fragmentary internal mould of ventral valve (CEGH-UNC 25958). $\bullet$ L - internal mould of ventral? valve (CEGH-UNC 25959). $\bullet$ M - fragmentary internal mould of ventral valve (CEGH-UNC 25957). • N - anterior region of unidentified valve (CEGH-UNC 25954). Scale bar $=5 \mathrm{~mm}$ unless otherwise noted. 

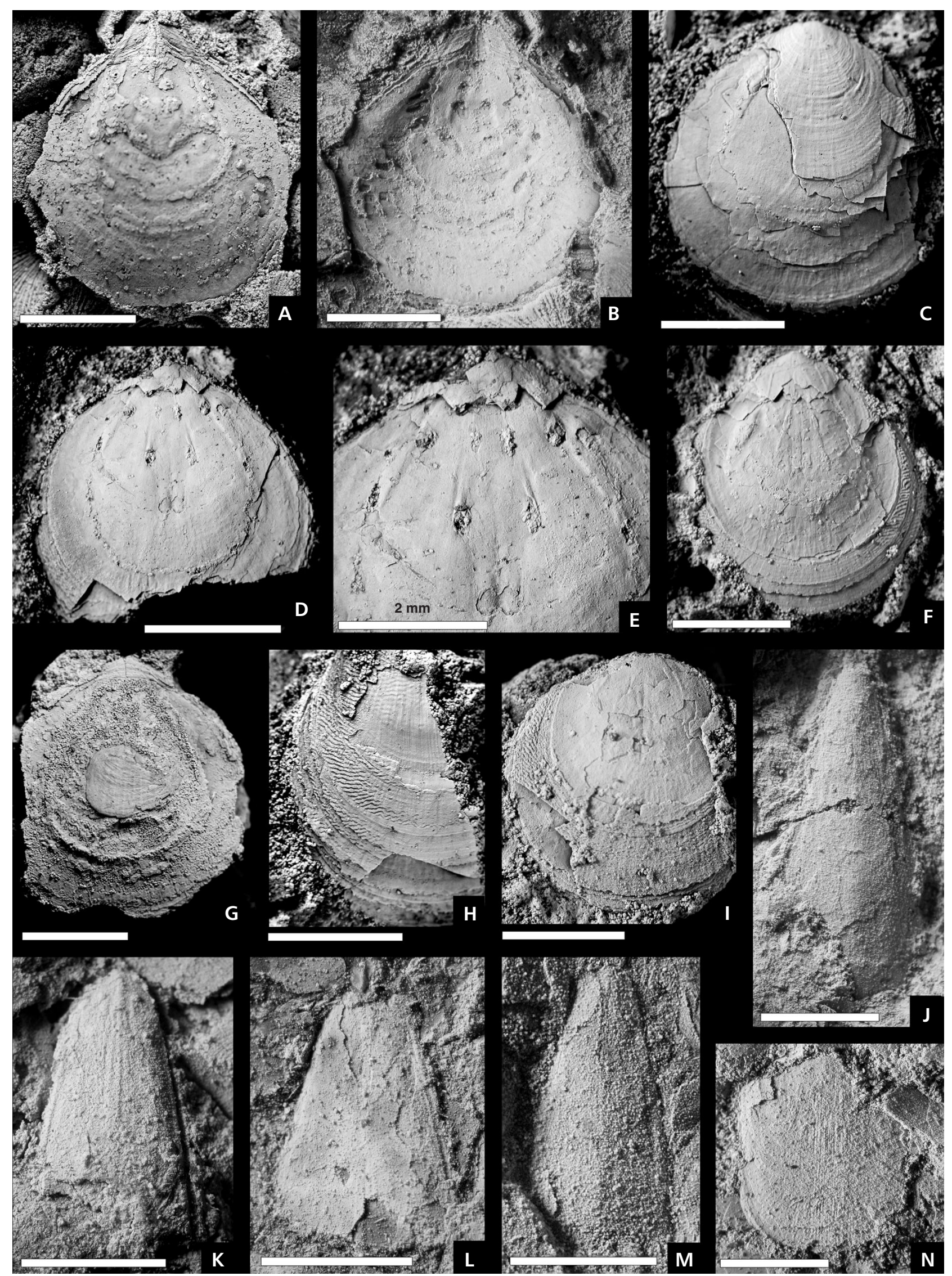


\section{Paratypes. - CEGH-UNC 25990-25999.}

Type locality. - Footpath to the Parcha village between Angosto de Lampazar and Abra de Sococha, Salta Province, Argentina.

Type horizon. - Boulders from the Devendeus Formation, lower Tremadocian.

Etymology. - Referring to the weakly convex dorsal valve.

Description. - Shell large, up to $14 \mathrm{~mm}$ long, thick-shelled, ventribiconvex. Ventral valve moderately convex, with maximum convexity at posterior third; outline elongate oval (length/width ratio 1.22 in one specimen) with maximum width located slightly beyond midlength; lateral and anterior margins uniformly curved, apical angle $\mathrm{ca} 95^{\circ}$. Ornamentation of divaricate undulating terrace lines well defined on flanks, effaced or indistinct on the central and anterior regions of the valve. Anterior third of the valve bearing distinct growth lamellae. Larval shell ornamentation not preserved.

Ventral valve with large apsacline pseudointerarea extending anteriorly for $15 \%$ of the valve length and occupying about 35\% of the maximum valve width. Pseudointerarea with well-defined widely divergent flexure lines separating large triangular inner propareas from narrow outer propareas. Pedicle groove wide, moderately deep, subtriangular, rapidly expanding anteriorly, with low narrow median ridge running longitudinally along the groove floor. Visceral area large, subrhomboidal, moderately raised anteriorly, poorly defined laterally and posteriorly, extending for $46 \%$ of the valve length in one specimen. Large suboval paired muscle scars at the front of the visceral area. Vascular system not impressed. Internal shell surface with large rounded pits roughly arranged in concentric rows following external growth lamellae.

Dorsal valve subcircular, gently convex at the posterior third, becoming nearly flat anteriorly; posterior margin broadly and evenly rounded. Pseudointerarea large, gently concave, arcuate, proportionally narrow, occupying about $42 \%$ of the valve width. Musculature complex, consisting of a pair of large oval medially-adjacent anterior lateral scars, a pair of smaller elongate impressions located at about one-third valve length from the umbo (corresponding probably to the central scars), a pair of widely separated relatively large scars located posteriorly (interpreted as posterolateral muscle scars), and a pair of minute rounded umbonal scars (Fig. 5E). Dorsal interior with broad, arcuate, deeply impressed vascula lateralia running almost parallel to the valve margin. Internal shell surface with scattered, randomly distributed small pits.

\section{Genus Leptembolon Mickwitz, 1896}

Type species. - Obolus (Leptembolon) lingulaeformis Mickwitz, 1896, p. 130, by original designation. Leetse beds (Floian), near Paldiski, northern Estonia.

\section{Leptembolon argentinum sp. nov.}

Figure 6A-M

Holotype. - CEGH-UNC 25938, internal mould of a pedicle valve (Fig. 6F, G).

Paratypes. - CEGH-UNC 25934b, 25939-25953.

Type locality. - Quebrada Humacha, eastern margin of Quebrada de Humahuaca, Jujuy Province, Argentina.

Type horizon. - Uppermost Santa Rosita Formation (Rupasca Member), level V24.

Etymology. - From Argentina.

Description. - Shell large, up to $20 \mathrm{~mm}$ long, thick-walled, subequally and moderately biconvex. Outline of ventral valve varying from elongate oval with maximum width at about midlength to rounded subrectangular or spatulate in the largest specimens. Ventral valve average length/width ratio 1.26 . Posterior region acuminate, subtending a mean angle of $95^{\circ}$. External ornamentation of densely spaced concentric growth lines, more distinct on the anterior third of the valve; exfoliated specimens with rounded radial costae superimposed on concentric ornamentation. Ventral pseudointerarea orthocline, undercut anteriorly, occupying about $13 \%$ of valve length and $65 \%$ of maximum valve width in one specimen. Flexure lines well defined in one specimen, defining subtriangular inner propareas and narrower outer propareas. Surface of pseudointerarea gently concave,

Figure 6. Leptembolon argentinum sp. nov. Locality: Tilcara Range, Quebrada Humacha. Age: late Tremadocian. • A, B - exterior (A) and internal mould (B) of dorsal valve (CEGH-UNC 25953). C - latex cast of exterior of ventral? valve (CEGH-UNC 25941). $\bullet$ D, E - latex cast of exterior (D) and internal mould of ventral valve (CEGH-UNC 25939b). • F, G - internal mould of ventral valve (F) and latex cast (G) (holotype CEGH-UNC 25947). - H - internal mould of incomplete ventral valve (CEGH-UNC 25931b). $\bullet$ I, J, M - partly exfoliated dorsal valve (I), internal mould (J) and latex cast (M) (CEGH-UNC 25950). $\bullet \mathrm{K}$ - internal mould of dorsal valve (CEGH-UNC 25934b). • L - internal mould of ventral valve (CEGH-UNC 25950a). Scale bar $=5 \mathrm{~mm}$. 

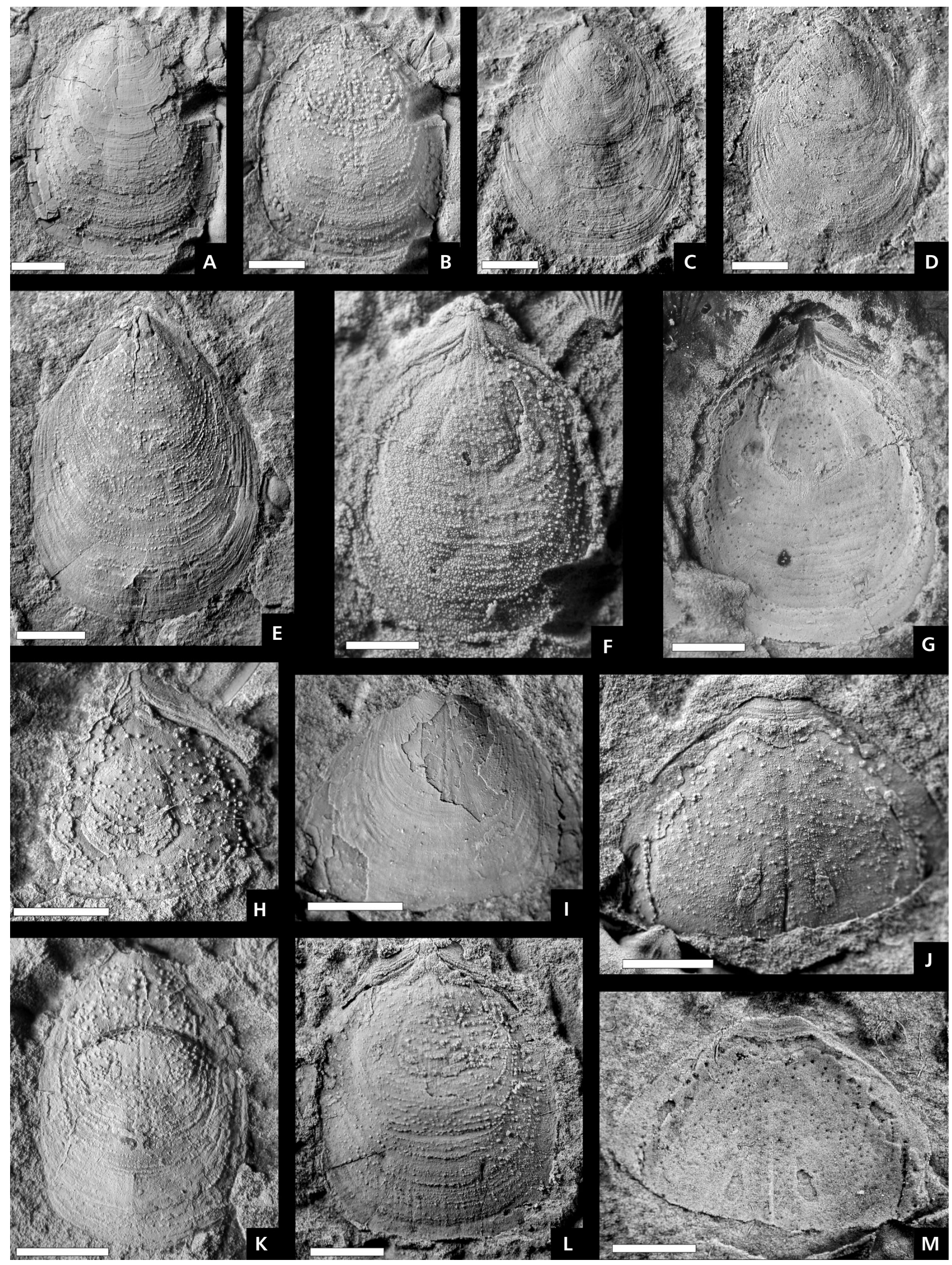
covered by growth lines curved backward in proximity to the pedicle groove and deflected anteriorly near the posterolateral margin. Pedicle groove large, triangular, moderately deep, flat-bottom, gently raised on the valve floor, its sides diverging $35-40^{\circ}$ anteriorly. Margins of pedicle groove delimited by a rounded carina. Ventral interior with variably developed, broadly rhomboidal visceral platform gently raised laterally and anteriorly, weakly impressed or indistinct in some specimens, extending to about valve midlength. Muscle scars and pallial markings not discernible.

Dorsal valve elongate suboval in outline. Dorsal pseudointerarea well-defined, gently arcuate, apsacline, occupying $32 \%$ of valve width in one specimen, its anterior edge raised above the valve floor; dorsal pseudointerarea surface gently concave with shallow, poorly defined median groove. Dorsal interior with distinct bladelike median ridge fading at about valve midlength. Visceral area weakly impressed. Central muscle scars deeply impressed, elongate suboval. Internal shell surface covered by small pits, their size increasing towards the flanks and on the posterior region of the valve.

Remarks. - The Argentine species significantly differs from the type species Leptembolon lingulaeformis (Mickwitz, 1896), from the Leetse beds (Floian) of northern Estonia in its suboval to subrectangular outline. Although this feature is rather variable in both the type material and the South Uralian specimens described by Popov \& Holmer (1994), none of the specimens in the L. argenitinum sample has a subtriangular outline. In addition, in the new species the anterior margin of the visceral platform is uniformly rounded, whereas in L. lingulaeformis it is angular and prolonged by a short median tongue ( $c f$. Popov \& Holmer 1984, fig. 48M). L. insons (Barrande, 1879), from the upper Tremadocian Mílina Formation of the Prague Basin (Havlíček 1982, Mergl 2002) is comparable to the Argentine species in its elongate suboval outline, but the Bohemian species differs in having a more acute apical angle ( $c a 5^{\circ}$ measured on two specimens illustrated by Mergl 2002, pl. 2, fig. 23 and pl. 3, fig. 1) and a narrower pedicle groove. The ventral platform is broadly similar in the two species, but the inadequate preservation of muscle scars in our material prevents a more detailed comparison. The new Argentine species can also be distinguished by its narrow and shorter dorsal median ridge and by having smaller and densely spaced internal pits, which in the Bohemian form are mostly confined to the posterior region of shell. The slightly younger (Floian) Bohemian species L. testis (Barrande, 1879) is closely comparable to $L$. insons except for its more subtriangular shell outline. The Argentine species differs from L. testis in having elongate oval shell outline, larger and more expanded pedicle groove, and a proportionally wider dorsal pseudointerarea.
Subfamily Glosselinae Cooper, 1956

\section{Genus Ectenoglossa Sinclair, 1945}

Type species. - Lingula lesueuri Roualt, 1850, p. 727, by original designation. Pebbles of Floian age in the Budleigh Salterton Pebble Bed (Triassic), Devon, England.

\section{Ectenoglossa sp.}

Figure 5J-N

Material. - CEGH-UNC 25954-25960. Quebrada Humacha, eastern margin of Quebrada de Humahuaca, Jujuy Province, Argentina. Uppermost Santa Rosita Formation (Rupasca and Humacha Members), levels V1d, Hm 11.

Description. - Shell large (a single nearly complete ventral valve over $18 \mathrm{~mm}$ long), strongly elongate, almost three times longer than wide (length/width ratio 2.80), acutely triangular in outline, with apical angle ranging from $32^{\circ}$ to $35^{\circ}$. Maximum shell width at about $75 \%$ of the shell length. Lateral margins straight, acutely divergent, becoming parallel-sided in the anterior quarter of the shell; anterior margin uniformly rounded. Ventral valve gently convex with steeply inclined lateral slopes. Ornamentation of poorly defined concentric growth lines; fine radial ribs present on the anterior part of decorticated specimens. Ventral pseudointerarea proportionally large, covered by distinct growth lines; pedicle groove large, subtriangular, moderately deep; flexure lines apparently lacking. Median ridge weak, confined to the posterior region, flanked by a pair of shallow sulci. Muscle scars and vascular canals not preserved. Internal features of dorsal valve unknown.

Remarks. - The present species is closely comparable to the type species Ectenoglossa lesueuri (Roualt, 1850) from the Lower Ordovician of France (Armorican Massif, Montaigne Noire) and England. The Argentine material differs in its rounded apical region and wider ventral pseudointerarea. In addition, in the European species the maximum shell width is situated at midlength and the lateral margins become subparallel beyond this point ( $c f$. specimen of E. lesueuri from the Budleigh Salterton Pebble Bed of Devon illustrated by Cocks 2000, fig. 3d). In all probability the material from Argentina is a new species of Ectenoglossa, but in absence of dorsal valves it is left in open nomenclature.

\section{Acknowledgements}

We thank the reviewers M. Mergl and I. Percival for their timely and thoughtful comments. This research was made possible through financial support from the Consejo Nacional de Investigaciones Científicas y Técnicas (CONICET), Grant PIP 112-201101-00803. 


\section{References}

Aceñolaza, F.G., Emig, C.C. \& GutiérRez-Marco, J.C. 2003. Lingulid shell beds from the Ordovician of Argentina, with notes on other peri-Gondwanan occurrences, 237-244. In Albanesi, G.L., Beresi, M.S. \& Peralta, S.H. (eds) Ordovician from the Andes. Instituto Superior de Correlación Geológica (INSUGEO), Serie Correlación Geológica 17.

Astini, R.A. 2003. The Ordovician Proto-Andean Basins, 1-74. In Benedetto, J.L. (ed.) Ordovician Fossils of Argentina. Secretaría de Ciencia y Tecnología, Universidad Nacional de Córdoba, Córdoba.

BABIN, C. 1993. Rôle des plates-formes gondwaniennes dans les diversifications des mollusques bivalves durant l'Ordovicien. Bulletin de la Societé Géologique de France 2, 141-153.

BARRANDE, J. 1879. Système silurien du centre de la Bohême. lère partie. Recherches Paléontologiques. Vol. 5. Classe des Mollusques. Ordre des Brachiopodes. 226 pp. Privately published, Prague \& Paris.

Bassett, M.G., Popov, L. \& Holmer, L.E. 1999. Organophosphatic brachiopods: pattern of biodiversification and extinction in the early Palaeozoic. Geobios 32, 145-163.

DOI 10.1016/S0016-6995(99)80026-6

BeDnARCZYC, W. 1999. Significance of the genus Thysanotos Mickwitz, 1986 for the Ordovician stratigraphy of East-Central Europe. Bulletin of the Polish Academy of Sciences, Earth Sciences 47, 15-25.

Benedetto, J.L. 2007. New Upper Cambrian-Tremadoc rhynchonelliform brachiopods from northwestern Argentina: evolutionary trends and early diversification of Plectorthoidea in Andean Gondwana. Journal of Paleontology 81, 261-285. DOI 10.1666/0022-3360(2007)81[261:NUCRBF]2.0.CO;2

Benedetto, J.L. 2013. Upper Ordovician brachiopods from the San Benito Formation, Cordillera del Tunari, Bolivia. Ameghiniana 50, 418-428. DOI 10.5710/AMGH.05.03.2013.558

BenedetTo, J.L. 2014. Tunariorthis, a new substitute name for Tunaria Benedetto, 2013 (Brachiopoda, Heterorthidae). Ameghiniana 51, 437. DOI 10.5710/AMGH.01.07.2014.2759

BenedetTo, J.L. \& Carrasco, P. 2002. Tremadoc (earliest Ordovician) brachiopods from the Purmamarca region and the Sierra de Mojotoro, Cordillera Oriental of northwestern Argentina. Geobios 35, 647-661.

DOI 10.1016/S0016-6995(02)00079-7

Benedetto, J.L. \& MuÑoz, D.F. 2013. Lipanorthis, un braquiópodo endémico del Ordovícico Inferior de la cuenca Andina Central. Reunión Anual de Comunicaciones de la Asociación Paleontológica Argentina, Abstracts, 36.

Benedetto, J.L. \& SÁnchez, T.M. 2003. The Ordovician radiation from a Gondwanan perspective: The early diversification of brachiopods and bivalves on mid- to high-latitude siliciclastic platforms, 245-250. In AlBanesi, G.L., BerEsI, M.S. \& Peralta, S.H. (eds) Ordovician from the Andes. Instituto Superior de Correlación Geológica (INSUGEO), Serie Correlación Geológica 17.

Benedetto, J.L., Vaccari, N.E., Waisfeld, B.G., Sánchez, T.M. \& Foglia, R.D. 2009. Cambrian and Ordovician paleobiogeography of Andean margin of Gondwana and accreted terranes, 199-230. In Bassett, M.G. (ed.) Early Palaeozoic Peri-Gondwanan Terranes: New Insights from Tectonics and Biogeography. The Geological Society of London, Special Publications 325.

Bergström, S.M., Chen, X., Gutierrez-Marco, J.C. \& Dronov,
A. 2009. The new chronostratigraphic classification of the Ordovician System and its relations to major regional series and stages and to $\delta^{13} \mathrm{C}$ chemostratigraphy. Lethaia 42, 97-107. DOI 10.1111/j.1502-3931.2008.00136.x

Brock, G.A. \& Holmer, L.E. 2004. Early Ordovician lingulate brachiopods from the Emanuel Formation, Canning Basin, Western Australia. Memoirs of the Association of Australasian Palaeontologists 30, 113-132.

Buatois, L.A. \& Mángano, M.G. 2003. Sedimentary facies and depositional evolution of the Upper Cambrian-Lower Ordovician Santa Rosita Formation in northwest Argentina. Journal of South American Earth Sciences 16, 343-363. DOI 10.1016/S0895-9811(03)00097-X

Buatois, L.A., Zeballo, F.J., Albanesi, G.L., Ortega, G., VAcCARI, N.E. \& Mángano, M.G. 2006. Depositional environments and stratigraphy of the Upper Cambrian-Lower Ordovician Santa Rosita Formation at the Alfarcito area, Cordillera Oriental, Argentina: Integration of biostratigraphic data within a sequence stratigraphic framework. Latin American Journal of Sedimentology and Basin Analysis 13, 1-29.

Cocks, L.R.M. 2000. The Early Palaeozoic geography of Europe. Journal of the Geological Society of London 157, 1-10. DOI 10.1144/jgs.157.1.1

Gutiérrez Marco, J.C. \& Aceñolaza, F.G. 1991. Ribeiria y Tolmachovia (Mollusca, Rostroconchia) en el Ordovícico Inferior de la Cordillera Oriental Argentina. Zentralblatt für Geologie und Paläontologie 1, 1799-1814.

Harper, D.A.T., Villas, E. \& Ortega, G. 2004. Lipanorthis Benedetto from the Tremadocian of NW Argentina reidentified as dalmanellidine: Significance for the origin and early radiation of punctate orthide. Lethaia 37, 271-279. DOI 10.1080/00241160410006537

Harrington, H.J. 1937. On some Ordovician fossils from Northern Argentina. Geological Magazine 74, 97-124. DOI $10.1017 /$ S0016756800088592

HarRington, H.J. 1938. Sobre las faunas del Ordoviciano inferior del Norte argentino. Revista del Museo de La Plata, nueva serie 1, 109-289.

HAVLíČEK, V. 1982. Lingulacea, Paterinacea and Siphonotretacea (Brachiopoda) in the Lower Ordovician sequence of Bohemia. Sborník geologických věd, Paleontologie 25, 9-82.

HavlíčEK, V. \& Branisa, L. 1980. Ordovician brachiopods of Bolivia. Rozpravy Československé akademie věd 90, 1-53.

KAYSER, E. 1897. Beiträge zur Kenntnis einiger paläozoischen Faunen Süd-Amerikas. Zeitschrift der Deutschen Geologische Gesellschaft 49, 274-317.

Mángano, M.G. \& Buatois, L.A. 1999. Ichnofacies models in Early Paleozoic tide-dominated quartzites: onshore-offshore gradients and the classic Seilacherian paradigm, 151-154. In Kraft, P. \& FatKa, O. (eds) Quo vadis Ordovician? Acta Universitatis Carolinae, Geologica 43(1/2).

Mángano, M.G. \& Buatois, L.A. 2004a. Reconstructing Early Phanerozoic intertidal ecosystems: ichnology of the Cambrian Campanario Formation in northwest Argentina, 17-38. In Webby, B.D., Mángano, M.G. \& Buatois, L.A. (eds) Trace Fossils in Evolutionary Palaeoecology. Fossils and Strata 51.

Mángano, M.G. \& Buatois, L.A. 2004b. Integración de estratigrafía secuencial, sedimentología e icnología para un análisis cronoestratigráfico del Paleozoico inferior del noroeste argentino. Revista de la Asociación Geológica Argentina 59, 273-280.

Marengo, L. 2010. Análisis tafonómico en los depósitos bioclásticos del grupo Santa Victoria (Cámbrico tardio- 
Ordovícico temprano), Cordillera Oriental Argentina. 206 pp. Ph.D. thesis, Facultad de Ciencias Exactas, Físicas y Naturales, Universidad Nacional de Córdoba, Argentina.

Mergl, M. 1984. Fauna of the Upper Tremadocian of Central Bohemia. Sborník geologických věd, Paleontologie 26, 9-46.

Mergl, M. 1996. New lingulate brachiopods from the Klabava Formation (Lower Ordovician, Arenig, Bohemia). Journal of the Czech Geological Society 41, 43-54.

Mergl, M. 1997a. Distribution of lingulate brachiopod Thysanotos in Central Europe. Věstník Českého geologického ústavu 72, 27-35.

MergL, M. 1997b. Orthid brachiopods with burrowing sculptures in the Lower Ordovician of Bohemia. Věstník Českého geologického ústavu 72, 127-140.

Mergl, M. 2002. Linguliformean and craniiformean brachiopods of the Ordovician (Třenice to Dobrotivá formations) of the Barrandian, Bohemia. Acta Musei nationalis Pragae, Series $B$ - historia naturalis 58, 1-82.

Moya, M.C. 1988. Lower Ordovician in the southern part of the Argentine Eastern Cordillera, 55-69. In BahlburG, H., Breitkreuz, C. \& Giese, P. (eds) The Southern Central Andes. Lecture Notes in Earth Sciences 17. Springer, Berlin.

Moya, M.C. 2002. The Ordovician basin of Northern Argentina, 281-294. In AceÑolaZA, F.G. (ed.) Aspects of the Ordovician System in Argentina. Instituto Superior de Correlación Geológica (INSUGEO), Serie Correlación Geológica 16.

MuÑoz, D.F. \& BenedetTo, J.L. 2013. Ontogenia de Nanorthis purmamarcaensis Benedetto (Brachiopoda) del Ordovícico Inferior de la Cordillera Oriental, noroeste de Argentina. Reunión Anual de Comunicaciones de la Asociación Paleontológica Argentina, Abstracts, 62.

Muñoz, D.F. \& BenedetTo, J.L. 2014. Bohemian-type obolids (Lingulate brachiopods) from the Lower Ordovician (Tremadocian) of Northwestern Argentina. $4^{\text {th }}$ International Paleontological Congress, Abstracts, 361. Mendoza.

Muñoz, D.F., Marengo, L.F. \& Waisfeld, B.G. 2012. Concentraciones de braquiópodos linguliformes de la Formación Santa Rosita (Furongiano-Tremadociano superior), Cordillera Oriental argentina: Tafonomía y distribución. $13^{\circ}$ Reunión Argentina de Sedimentología, Abstracts, 150-151. Salta.

Muñoz, D.F., Meroi Acerito, F.R. \& Waisfeld, B.G. 2013. Concentraciones de braquiópodos punctuados (Lipanorthis Benedetto) en el Ordovícico Inferior de la Cordillera Oriental, Argentina. Reunión Anual de Comunicaciones de la Asociación Paleontológica Argentina, Abstracts, 62.

Ortega, G. \& Albanesi, G.L. 2005. Tremadocian graptoliteconodont biostratigraphy of the South American Gondwana margin (Eastern Cordillera, NW Argentina). Geologica Acta $3,366-371$.

Popov, L. \& Holmer, L.E. 1994. Cambrian-Ordovician lingulate brachiopods from Scandinavia, Kazakhstan, and South Ural Mountains. Fossils and Strata 35, 1-156.

Roualt, M. 1850. Note preliminaire sur une nouvelle formation decouverte dans le terrain Silurien inférieur de la Bretagne. Bulletin de la Société géologique de France (series 2) 7, 724-744.

Salas, M.J. \& VAcCari, N.E. 2012. New insights into the early diversification of the Ostracoda: Tremadocian ostracods from the Cordillera Oriental, Argentina. Acta Palaeontologica Polonica 57, 175-190. DOI 10.4202/app.2009.1110

SÁncheZ, T.M. 2005. New Bivalvia and Rostroconchia from the Early Ordovician (late Tremadoc-middle Arenig) of north- western Argentina. Journal of Paleontology 79, 538-547. DOI 10.1666/0022-3360(2005)079<0532:NBARFT >2.0.CO;2

SÁNCHEZ, T.M. 2008. The early bivalve radiation in the Ordovician Gondwanan basins of Argentina. Alcheringa 32, 223-246. DOI 10.1080/03115510802096044

SÁncheZ, T.M. \& BABIN, C. 2003. Distribution paléogeographique des Mollusques Bivalves durant l'Ordovicien. Geodiversitas 25, 243-259.

SAVAzZI, E. 1986. Burrowing sculptures and life habits in Paleozoic lingulacean brachiopods. Paleobiology 12, 46-63.

Szduy, K., Hammann, W. \& Villas, E. 2001. The Upper Tremadoc fauna from Vogtendorf and the Bavarian Ordovician from Frankenwald (Germany). Senckenbergiana lethaea 81, 207-261.

Topper, T.P., Harper, D.A.T. \& BRock, G.A. 2013. Ancestral billingsellides and the evolution and phylogenetic relationships of early rhynchonelliform brachiopods. Journal of Systematic Palaeontology 11, 821-833. DOI 10.1080/14772019.2012.728253

Tortello, M.F. \& RaO, R.I. 2000. Trilobites y conodontes del Ordovícico temprano del Angosto de Lampazar (provincia de Salta, Argentina). Boletín Geológico y Minero ITGM, España $111,61-84$.

TuRnER, J.C. 1960. Estratigrafía de la sierra de Santa Victoria y adyacencias. Boletín de la Academia Nacional de Ciencias 41, 163-169.

Villas, E., Herrera, Z.A. \& Ortega, G. 2009. Early orthid brachiopods from the Tremadocian (Lower Ordovician) of Northwestern Argentina. Journal of Paleontology 83, 604-613. DOI 10.1666/08-165R.1

WaISFELD, B.G. \& VACCARI, N.E. 2003. Trilobites, 295-409. In Benedetto, J.L. (ed.) Ordovician Fossils of Argentina. Universidad Nacional de Córdoba, Secretaría de Ciencia y Tecnología, Córdoba.

WAisfeld, B.G. \& VACCARI, N.E. 2008a. Bioestratigrafía de trilobites del Paleozoico inferior de la Cordillera Oriental, 119-127. In Coira, B. \& Zappettini, E.O. (eds) Actas $18^{\circ}$ Congreso Geológico Argentino. Jujuy.

WAISFELD, B.G. \& VACCARI, N.E. 2008b. Oxygen controlled Early Ordovician trilobite assemblages: the Thysanopyge fauna from Northwestern Argentina, 421-425. In RÁBANO, I., Gonzalo, R. \& García Bellido, D. (eds) Advances in Trilobite Research. Fourth International Trilobite Conference, Cuadernos del Museo Geominero 9. Toledo.

Williams, H. \& Stevens, R.K.1991. Late Tremadoc graptolites from Western Newfoundland. Palaeontology 34, 1-47.

Zeballo, F.J. \& Albanesi, G.L. 2013. New conodont species and biostratigraphy of the Santa Rosita Formation (upper Furongian-Tremadocian) in the Tilcara Range, Cordillera Oriental of Jujuy, Argentina. Geological Journal 48, 170-193. DOI $10.1002 / \mathrm{gj} .2425$

Zeballo, F.J., Albanesi, G.L. \& Ortega, G. 2005. Conodontes y graptolitos de las formaciones Alfarcito y Rupasca (Tremadociano) en el área de Alfarcito, Tilcara, Cordillera Oriental de Jujuy, Argentina. Parte 1: Bioestratigrafía. Ameghiniana 42, 39-46.

Zeballo, F.J., Albanesi, G.L. \& Ortega, G. 2008. New late Tremadocian (Early Ordovician) conodont and graptolite records from the southern South American Gondwana margin (Eastern Cordillera, Argentina). Geologica Acta 6, 127-141.

Zeballo, F.J. \& Tortello, M.F. 2005. Trilobites del Cámbrico tardío-Ordovícico temprano del área de Alfarcito, Tilcara, Cordillera Oriental de Jujuy, Argentina. Ameghiniana 42, 127-142. 